\title{
Exchange rate regime in India \& role of central bank in exchange rate management
}

\author{
Shivali Dhameja* Namita Jain ** \\ *Assistant Professor, Shri Ram college of commerce, DU \\ Research Scholar, Department of commerce, DSE \\ **Assistant Professor, Shri ram college of commerce,DU
}

\begin{abstract}
This paper studies exchange rate regimes pursued in Indian economy since past decades. The paper has attempted to study transformation from fixed regime to floating or pegged arrangements in India \& also the challenges associated with these reforms as brought in 1992. Further, several authors have identified variables to assess the presence of central bank intervention even under the system of floating exchange rate \& efficiency of their efforts in targeting the real exchange rate. Finally, it has identified that as per impossible trinity, given the open capital account, a bipolar view seems appropriate in India.
\end{abstract}

Keywords: Exchange rate, de facto regimes, monetary policy

\section{Review of literature}

For any small open economy, exchange rates are universally regarded as the key relative price to determining its macroeconomic configuration. However, a question as to what constitutes the appropriate or optimal exchange rate regime for developing countries and emerging market economies has long been in the domain of intense debates among academics and policymakers alike. The exchange rate policy influences not only net external trade balances through the competitiveness of tradable goods but also the internal resource allocation between tradables and nontradables through changes in the real exchange rates ${ }^{\cdot(1)}$

The exchange rate is considered a relative price, which restores equilibrium in real or financial markets. As such, exchange rate movements can only result from changes in underlying 'fundamentals', which require an adjustment in relative prices (Harvey 2001). Jeanne and Rose (1999) suggest that whilst the volatility in exchange rates is generated both by fundamentals and noise, the source of excessive exchange rate volatility (i.e., speculative bubbles) is attributed to the presence of noise traders.

The choice of an optimal exchange rate regime is one of the major unresolved questions of international macroeconomics. In the most major currency crises, intermediate regimes have been most popular. Looking at the financial market integration, hard pegs and free float are the only compatible regimes i.e the bipolar view. Thus the countries with high capital mobility should be abandoning intermediate regimes . However, a country's actual exchange rate policy can differ from its official notification ${ }^{(2)}$ Intermediate regimes such as a target zone or crawling band system may be one of best options for many developing, emerging market economies, as they combine elements of both 'flexibility' and 'stability. a central issue to resolve for sustaining any intermediate regime, however is how to establish the credibility of policymakers' commitment to such exchange rate regimes ${ }^{(1)}$

The first step towards fundamental reform was announced in the budget of 1992, as the so-called 'partial convertibility' scheme or, more formally, the liberalised exchange rate management aystem (LERMS).The introduction of current account convertibility and move towards introduction of capital account convertibility has helped the Rupee-Dollar exchange rate to attain more flexibility as required by the market conditions. The opening up of the economy helped to attract huge inflows of foreign capital, both FDI and FII and this helped the exchange rate to stabilize. The Asian crisis of 1997-98 did not have a lingering impact on Rupee-Dollar exchange rate ${ }^{(3)}$

Reinhart and Rogoff (2003) identify the Indian currency regime over 1979-2001 as a "peg to the US dollar.This period marks shift to floating exchange rate regime. India shifted from an adjustable-peg to a market-based exchange rate regime in 1993. The empirical characteristics of this period have been nominal and real exchange rate stability i.e low exchange rate volatility \& break in the long-term depreciation trend of the real exchange rate \&lastly, increase in reserves' volatility which were found to be interrelated. The primary objective of exchange rate management by Indian Central bank was to target the real exchange rate in an effort to lean against the wind during $1993-99^{.(4)}$

Most of the studies have looked at variables like exchange rates, nominal and real interest rates, international reserves and commodity prices as indicators of policy intervention and external shocks. As contrary to the belief that fixed exchange rate system via policy intervention is dead after shift to floating 
system, Calvo\& Reinhart(2000) demonstrates that the 'float' was extensively managed between 1993 and 1999 to achieve nominal and real exchange rate stability despite a policy ostensibly meant to allow the rupee to float.

The basic choice is between a floating system and some sort of a pegged arrangement. if the choice of a country is a pegged arrangement, then too there are a series of altenatives available which include a single currency peg (the dollar/sterling/any other convertible currency), a basket peg (SDR or specially constituted multi-currency basket), peg to selected economic indicators, etc. It would be impossible under a generalised floating regime for a country endogenously to influence or stabilise entirely the exchange rates of its currency against all major currencies. What can be attempted at best is to moderate the average variation of its currency over time and thus moderate the impact of exchange rate variations originating from exogenous factors on its trade and payments. A single currency peg either to the sterling or the dollar will have the potential to move the rates of the rupee sharply against third currencies along with the peg currency and such movements may not be in accord with the domestic economic and balance of payment needs of India. ${ }^{(5)}$

The 'fear of floating' has been prevalent among emerging market economies (Calvo and Reinhart 2002). Even among the emerging economies of East Asia, many of which managed to stage a quick recovery from the devastating Asian crisis of 1997-98, we find a continuing adherence to the East Asian dollar pegged regimes (McKinnon and Schnabl 2004). Manyemerging economies have, instead, opted to hold large amounts of international reservesfor self-insurance purposes((Jeanne 2007; Miller and Zhang 2007).

Michael DebabrataPatra\&SitikanthaPattanaikdeveloped some objective indicators i.e., indices of exchange market pressure, intervention activity and monetary conditions in order to assess the efficacy, in terms of both timing and magnitude, of policy measures in assuaging exchange market pressures\& concluded that policy action has been successful in relieving exchange market pressure. ${ }^{(6)}$

The central banks across the world repeatedly intervene in foreign exchange markets. One of the approaches have been sterilised intervention i.ethe sale or purchase of foreign currency assets, and an open market operation involving the purchase or sale of government securities (in the same size as the first transaction). The open market operation effectively offsets or sterilizes the impact of the intervention on the monetary base. If sterilised intervention is to be made effective in its impact on exchange rate, intervention has to be reinforced bymonetary policy measures. Unsterilised intervention, by causing changes in countries' money supplies, delivers a monetary shock to the exchange rate in much the same manner as monetary policy; in fact, under conditions of perfect substitutibility, monetary policy and unsterilised intervention are undistinguishable in their impact on the exchange rate. Unsterilised intervention is to be regarded as an instrument of monetary policy with no independent power over the foreign exchange market. Investigating whether unsterilised intervention to stabilise the exchange rate is compatible with a regime in which monetary aggregates are used as intermediate targets ${ }^{(7)}$

The more the central bank of any country focuses on currency policy, the more it loses monetary autonomy. Countries could attain autonomy in both currency policy as well as monetary policy but only by closing capital account. With a closed capital account, the speculators are not able to move capital across the border. However with a steady increase in openness on the capital account in recent decades, many countries are forced to trade off between having a currency policy and monetary policy autonomy.

Earlier 'India had a system of strong capital controls which made it possible for central bank to operate a fixed exchange rate regime \& have monetary policy autonomy. India has neither a complete open capital account nor a completely fixed exchange rate. The current framework comprises a pegged exchange rate with extremely low volatility and an effort at monetary policy autonomy ${ }^{(7)}$

Impossible trinity which consists of the assertion that no country can simultaneously have an open capital account, a fixed exchange rate, and monetary policy independence.In the Indian case, a system of strong capital controls backed by the Foreign Exchange Regulation Act (FERA) was present at the outset. This made it possible to have a pegged exchange rate and monetary policy autonomy over the 1973-93 period. Patnaik (2005) shows that there was a loss of monetary policy autonomy in the $1990 \mathrm{~s}^{(8)}$ Resorting to this thesis, it is argued that the only exchange rate regimes that remainviable in an era of free cross-border capital mobility are the two corners positions withinthe trinity, i.e. either pure floating or hard pegs since only two out of the three can be mutually consistent ${ }^{(1)}$

Empirical literature on currency regimes suggests that from August 1991 to June 1995, India's currency regime is best described as a de facto peg to the US dollar, while from then to end 2001 it was a de facto crawling peg ${ }^{(8)}$

In India, as in most developing countries, there has been a distinction between the de facto and the de jure currency regime. Patnaik (2003) argues that there is a de facto pegged exchange rate. As is typical with pegged exchange rates, the nominal rupee-dollar exchange rate has had low volatility, while all other measures of the exchange rate have been more volatile. The rupee-dollar spot market is a pegged exchange rate. It is not a floating rate. It is not a random walk. Violations of market efficiency are detected. It may hence be possible for economic agents to form useful predictions of future currency movements. ${ }^{(9)}$ 
India's exchange rate crisis has been attributed to continued current account deficits leading up to the crisis made worse by problems related to the Gulf War; and a loss of confidence in the government as political problems compounded the weak credibility associated with high fiscal deficits.Looking at the 1991 currency crisis, The evidence indicates that overvaluation as well as current account deficits and investor confidence played significant roles in the sharp exchange rate depreciation. ${ }^{(10)}$

The first step towards this was announced in the budget of 1992, as the so-called 'partial convertibility' scheme or, more formally, the liberalised exchange rate management system (LERMS). The authorities have had exchange rate targets in mind but the targets have shifted from time to time often known as discretionary or dirty crawl of exchange rate. Apart from making the exchange rate more market oriented, Indian authorities have also articulated other objectives of exchange rate policy which are found to be incompatible with clean floating. These are a) to iron out day to day volatility; b) to maintain a competitive exchange rate; c) to accumulate sizeable foreign exchange reserves. Among others, there was apparently more general macro economic objectives like to secure low inflation \& cyclical stability ${ }^{(6)}$

\section{Scattered quotes from Rangarajan and Prasad (2008)}

"With an open economy and large capital inflows, management of the exchange ratebecomes an independent concern.... Managed exchange rate system offers an attractive "middle way" between the polar choices of fixed and free floating exchange rates. The element of fixity helps avoid the volatility that might otherwise arise from cyclical and other reversible fluctuations in the current account position... Thus, instead of arguing for the exclusive use of any one of the instruments, there must be a judicious mix of all of the three instruments." (11)

There is a gap, which has been closing, between what the Reserve Bank of India (RBI) says and what it does. After the reforms and devaluation of the early nineties the nominal exchange rate was kept more or less fixed; but the RBI would say it was amarket determined rate even as it kept buying FX to keep the Rupee fromappreciating as foreign inflows began to flood in ${ }^{(11)}$

\section{Conclusion}

From the review of literature, we can conclude that India follows a de facto pegged exchange rate system. India is an open economy with large capital movements. Thus, the only exchange rate regimes that remain viable in an era of free cross-border capital mobility are the two corners positions within the trinity, i.e. either pure floating or hard pegs.

\section{Bibliography}

[1]. Annina Kalten brunner and Machiko Nissanke. 2009. The Case for an Intermediate "Exchange Rate Regime with Endogenizing Market Structures and Capital Mobility".

[2]. Andrea Bubula and Inciotker- robe .2002 . "The evolution of exchange rate regime since 1990: Evidence from de facto policies". IMF working paper

[3]. Golaka C Nath \& Dr. Y V Reddy. 2003 "Long Memory in Rupee-Dollar Exchange Rate - An Empirical Study"

[4]. Renu kohli.2002. "Real exchange rate stabilisation and managed floating: exchange rate policy in India, 1993-2001". Journal of Asian Economics 14 (2003) 369-387.

[5]. S K Verghese.1979. "Exchange rate of Indian rupee since its basket link". Economic and Political Weekly, Vol. 14, No. 28 (Jul. 14, 1979), pp. 1160-1165

[6]. Michael Debabrata Patra \& Sitikantha Pattanaik. "Exchange Rate Management in India : An Empirical Evaluation"

[7]. Suman Bery, Barry Bosworth, Arvind Panagariya .2004. India Policy Forum .Vol 1

[8]. Ila Patnaik. " Indian Currency Regime and Its Consequences". Economic and Political Weekly, Vol. 42, No. 11 (Mar. 17-23, 2007), pp. 911-913

[9]. Ajay Shah and Ila Patnaik. 2007. "The Elusive Quest for a SustainableCurrent Account Deficit”. India’s Experience with Capital Flows. National Bureau of Economic Research

[10]. Valerie Cerra and Sweta Chaman Saxena.2002. "What Caused the 1991 Currency Crisis in India?”.IMF Staff Papers.Palgrave Macmillan Journals

[11]. Ashima Goyal. 2010. "Evolution of India's exchange rate regime”. WP Dec 2010. Indira Gandhi Institute of Development Research 